\title{
PENGARUH PEMBERIAN SARI UBI UNGU (Ipomea batatas L.) TERHADAP KADAR HIGH SENSITIVITY C-REACTIVE PROTEIN (hs-CRP) PADA TIKUS SPRAGUE DAWLEY DENGAN PAKAN TINGGI LEMAK
}

\author{
Irene Nucifera Puspitadewi ${ }^{1}$, Ani Margawati ${ }^{1}$, Hartanti Sandi Wijayanti ${ }^{1}$ \\ ${ }^{1}$ Departemen Ilmu Gizi, Fakultas Kedokteran, Universitas Diponegoro \\ Jln. Prof. H. Soedarto, SH., Semarang, Telp (024) 76402881, Email : gizifk@undip.ac.id
}

\begin{abstract}
Background: Dietary fat composition can interfere the development of obesity which alter fat oxidation. Fat oxidation may affect inflammation which is characterized by increasing High Sensitivity C-Reactive Protein (hs-CRP) levels. Purple sweet potato rich in antioxidant especially anthocyanin that may decrease High Sensitivity C-Reactive Protein (hs-CRP) levels.

Objective: To analyze the effect of purple sweet potato on High Sensitivity C-Reactive Protein (hs-CRP) levels in rats with high fat diets.

Methods: The study was a true experimental study with pre-post test control design. Total of 24 rats were divided into four groups i.e. negative control, positive control, treatment 1 and treatment 2. Treatment 1 dan 2 were given purple sweet potato with dose $2 \mathrm{gram} / 200 \mathrm{gram}$ body weight and $3 \mathrm{gram} / 200 \mathrm{gram}$ body weight respectively for 6 days. High Sensitivity C-Reactive Protein (hs-CRP) were measured before and after treatment. hs-CRP levels were analyzed using ELISA (Enzyme Linked Immunosorbent Assay) method.

Result: The delta of hs-CRP before and after treatment in negative control, positive control, treatment 1 and treatment 2 were $0.4 \pm 0.20,-0.07 \pm 4.70,-4.3 \pm 0.79$ and $-8.1 \pm 0.45$ respectively. There were signifficant differences in $h s$-CRP levels after treatment between groups $(p=<0.001)$.Treatment 2 group had a highest reduction of hs-CRP levels (percent delta was $33,33 \%$ with $p=<0.001$ )
\end{abstract}

Conclusion: Purple Sweet Potato can decrease High Sensitivity C-Reactive Protein (hs-CRP) levels significantly.

Keyword: Purple Sweet Potato, High Sensitivity C-Reactive Protein (hs-CRP)

\section{ABSTRAK}

Latar Belakang: Komposisi makanan tinggi lemak dapat menjadi faktor terjadinya obesitasyang menyebabkan oksidasi lemak. Oksidasi lemak dapat menyebabkan inflamasi yang dikarakterisasikan dengan tingginya kadar High Sensitivity C-Reactive Protein (hs-CRP). Ubi ungu kaya akan antioksidan terutama antosianin yang mungkin dapat menurunkan kadar hs-CRP. Penelitian ini bertujuan untuk mengetahui pengaruh sari ubi ungu terhadap kadar hs-CRP tikus sprague dawley dengan pakan tinggi lemak.

Metode: Jenis penelitian ini adalah true experimental dengan pre-post test control group design. 24 tikus sprague dawley jantan dibagi menjadi 4 kelompok yaitu kontrol negatif, kontrol positif, perlakuan 1 dan perlakuan 2. Perlakuan 1 dan 2 diberikan sari ubi ungu dengan dosis 2 gram/200grBB dan 3 gram/200grBB berturut-turut selama 6 hari. Sebelum dan sesudah perlakuan, kadar hs-CRP dianalisis dengan menggunakan metode ELISA (Enzyme Linked Immunosorbent Assay).

Hasil: Selisih kadar hs-CRP pada keolompok kontrol negatif, kontrol positif, perlakuan 1 dan perlakuan 2 adalah $0.4 \pm 0.20,-0.07 \pm 4.70,-4.3 \pm 0.79$ dan $-8.1 \pm 0.45$. Terdapat perbedaan signifikan kadar hs-CRP antar kelompok sesudah intervensi $(p=<0.001)$. Pada kelompok perlakuan 2 terdapat penurunan yang paling tinggi (persen delta 33,33\% dengan nilai $p=<0.001$.

Simpulan: Sari ubi ungu dapat menurunkan kadar High Sensitivity C-Reactive Protein (hs-CRP) secara signifikan.

Kata kunci: Ubi Ungu, kadar High Sensitivity C-Reactive Protein (hs-CRP)

\section{PENDAHULUAN}

Obesitas merupakan suatu masalah kesehatan karena prevalensinya yang meningkat di berbagai negara. ${ }^{1}$ Prevalensi overweight dan obesitas meningkat dari $8 \%-30 \%$ pada laki-laki dan $8-52 \%$ pada perempuan menurut WHO Bagian Asia Tenggara. $^{2} \mathrm{Di}$ Indonesia, prevalensi obesitas meningkat, dari tahun 2007 hingga tahun 2013 yaitu10,3\% di tahun 2007 menjadi 15,4\% di tahun
2013. ${ }^{3}$ Hasil dari Riset Kesehatan Dasar (Riskesdas) 2013 menunjukkan penduduk Indonesia usia dewasa mengalami kelebihan berat badan dengan 14,8\% diantaranya merupakan obesitas dengan IMT $>27$ $\mathrm{kg} / \mathrm{m}^{2}{ }^{4}$

Obesitas terjadi karena ketidakseimbangan antara asupan energi dengan energi yang dikeluarkan dan kelebihan energi tersebut disimpan dalam bentuk adiposit. Konsumsi makanan yang berlebihan 
menyebabkan asupan energi tinggi dan kurangnya energi yang dikeluarkan disebabkan oleh rendahnya metabolisme tubuh, aktivitas fisik dan efek termogenesis makanan yang ditentukan oleh komposisi makanan. ${ }^{1,5}$ Kelebihan jaringan lemak juga berkaitan dengan pola konsumsi makanan tinggi lemak yang menyebabkan beragam gangguan metabolisme seperti hiperfagia, menurunnya aktivitas lipolisis, menurunnya sekresi dan atau sensitivitas leptin, resistensi insulin dan obesitas. ${ }^{6}$

Obesitas menimbulkan berbagai dampak masalah kesehatan. Pola konsumsi makanan tinggi lemak pada obesitas menyebabkan munculnya inflamasi yang disertai dengan tingginya kadar $C$ Reactive Protein (CRP) dan menimbulkan beberapa penyakit degenaratif. ${ }^{7,8}$ Akumulasi lemak yang berlebihan di dalam tubuh membuat jaringan adiposa mensintesis dan melepas adipositokin sehingga meningkat kadarnya dan diikuti dengan peningkatan mediator-mediator inflamasi, salah satunya adalah interleukin-6(IL-6) yang akan menyebabkan tingginya kadar CRP. ${ }^{9}$ Penyakit degeneratif yang muncul seperti diabetes melitus tipe 2, penyakit kardiovaskular, stroke, kanker, crohn's disease dan komplikasi non-metabolik lainnya seperti arthritis. ${ }^{10,11}$

Pada beberapa penelitian menyebutkan dengan mengonsumsi makanan tinggi antioksidan seperti sayur, buah dan sumber antioksidan lainnya akan mengurangi kadar CRP. Penelitian yang dilakukan di Eropa melaporkan bahwa ada hubungan yang signifikan antara tinggi konsumsi sayuran dan status inflamasi anak. ${ }^{7}$ Ubi ungu memiliki potensi dalam menurunkan kadar hs-CRP karena kandungan antioksidan dan komposisi kimia yang terkandung dalam ubi ungu. ${ }^{12,13}$ Antioksidan pada ubi ungu berasal dari antosianin, $\beta$-karoten, tokoferol dan asam askorbat, tetapi antioksidan yang paling banyak terdapat ubi ungu adalah antosianin dengan kadarnya $110,51 \mathrm{mg}$ per 100 gram ubi ungu. Antosianin yang cukup tinggi berperan besar dalam penurunan hsCRP walaupun terdapat antioksidan lain yang juga dapat menurunkan kadar hs-CRP tersebut. ${ }^{14,15,16}$ Antosianin menghambat ekspresi gen yang terlibat dalam banyak proses inflamasi. Gen-gen tersebut ditranskripsi oleh nuclear factor-kB (NF-kB) yang berperan dalam mentranskripsi beberapa sitokin proinflamasi seperti TNF- $\alpha$, IL-1 $\beta$, Il-6. ${ }^{17}$

Intervensi ubi ungu dipilih oleh peneliti karena jika diterapkan kepada masyarakat mudah untuk memperolehnya, cara pengolahannya mudah. Selain itu antosianin pada ubi ungu larut dalam air sehingga dengan pengonsumsian sedikit akan efektif. ${ }^{16}$ Pada penelitian sebelumnya menunjukkan adanya pengaruh pemberian ubi ungu yang berperan sebagai antioksidan dalam mengurangi kadar
Malondialdehyde (MDA), serum alanine aminotransferase dan aktivitas aspartate aminotransferase pada tikus dengan penyakit hati. ${ }^{18,19}$ Penelitian lain menunjukkan adanya efek anti obesitas yaitu dapat menurunkan berat badan pada tikus yang diberikan pakan tinggi lemak selain itu dapat memperbaiki intoleransi glukosa, resistensi insulin, mengurangi stres oksidatif pada ginjal dan menghambat aktivasi persinyalan dari NF-kB yang berperan dalam menurunkan kadar CRP. ${ }^{20}$ Oleh karena itu penelitiingin mengetahui pengaruh pemberian sari ubi ungu terhadap kadar hs-CRP pada tikus sprague dawley yang diberi pakan tinggi lemak.

\section{METODE}

Jenis penelitian ini adalah true eksperimental dengan rancangan pre-post test control design group. Penelitian dan pengumpulan data dilakukan dalam rentang waktu Mei 2018 - Juni 2018. Subjek penelitian yang digunakan adalah tikus jantan dengan galur sprague dawley (Rattus norvergicus). Kriteria inklusi yang digunakan yaitu tikus sprague dawley jantan, usia 9 minggu, berat badan 100-150 gram, kondisi sehat dan jenis kelamin jantan. Kriteria eksklusi yaitu tikus mati saat penelitian berlangsung, tikus mengalami perubahan perilaku (kehilangan nafsu, stres dan lemas), tikus mengalami penurunan berat badan $10 \%$ dari berat badan awal, tidak mengalami penambahan berat badan setelah 36 hari pemberian pakan tinggi lemak.

Penentuan besar subjek minimal menurut WHO yaitu jumlah sampel minimal 5 ekor hewan coba pada tiap kelompok dan ditambah dengan batas minimal $10 \%$ atau 1 ekor menjadi 6 ekor tikus tiap kelompok sehingga dibutuhkan 24 ekor tikus. Tikus dipilih secara acak yang dibagi menjadi kelompok kontrol negatif (K-) yang dikondisikan normal yaitu pemberian pakan standar dan 18 tikus diberikan pakan tinggi lemak dan dikelompokkan menjadi kontrol positif $\mathrm{K}(+)$, perlakuan 1 (P1) dan perlakuan 2 (P2) berdasarkan metode simple random sampling. Kelompok $\mathrm{K}(-)$ dan $\mathrm{K}(+)$ tidak diberikan intervensi, kelompok P1 dan P2 diberikan sari ubi ungu dengan dosis bertingkat.Variabel bebas dalam penelitian ini adalah pemberian sari ubi ungu sedangkan variabel terikat penelitian adalah kadar hs-CRP. Variabel terkontrol yaitu galur tikus hewan coba, umur hewan coba, jenis kelamin coba, pakan hewan coba, kandang hewan coba dan berat badan hewan coba.

Dosis pemberian berdasarkan dosis antosianin yang dianjurkan yaitu 25-215 $\mathrm{mg} /$ orang/hari dan jika dikonversikan ke tikus adalah 0,45-3,87 $\mathrm{mg} / 200 \mathrm{grBB}$ tikus. ${ }^{21}$ Berdasarkan perhitungan yang dilakukan selanjunya mendapatkan dosis ubi untuk kelompok perlakuan 1 dan perlakuan 2 adalah 2 gram ubi/200grBB dan 3 gram 
ubi/200grBB selama 6 hari. Pada P1 memiliki kandungan antosianin 2,21 mg/200grBB sedangkan pada kelompok P2 memiliki kandungan antosianin 3,31 mg/200grBB.Selain diberikan sonde intervensi ubi ungu, tikus juga diberikan pakan standar HiProvite 594.

Tahapan penelitian yang dilakukan adalah tikus sebanyak 24 ekor diaklimatisasi selama 14 hari dengan diberi pakan standar dan minum akuades $a d$ libitum. Setelah masa adaptasi 14 hari, tikus diberi pakan tinggi lemak selama 36 hari. Pakan tinggi lemak yang diberikan adalah kuning telur bebek $4 \mathrm{ml}$ dan minyak babi $1,5 \mathrm{ml}$ yang dihomogenisasi dengan $2 \mathrm{x}$ pemberian sonde. Setelah tikus diberikan pakan tinggi lemak, diberikan intervensi sari ubi ungu pada kelompok P1 dan P2. Tahapan penelitian tersebut dilakukan di Laboratorium Hewan Coba Fakultas Kedokteran Universitas Diponegoro.

Data yang dikumpulkan berupa berat badan tikus sebelum dan setelah pemberian pakan tinggi lemak, sebelum dan setelah pemberian intervensi sari ubi ungu dan kadar hs-CRP sebelum dan sesudah intervensi. Berat badan diukur setiap hari yang dimulai sejak awal pemberian pakan tinggi lemak. Pemeriksaan darah tikus dilakukan 2 kali yaitu setelah hari terakhir pemberian pakan tinggi lemak atau sebelum dilakukan intervensi sari ubi ungu (data pre-test). Pemeriksaan darah kedua adalah setelah pemberian intervensi sari ubi ungu yaitu sehari setelah pemberian intervensi terakhir (data post-test). Pengukuran kadar hs-CRP dilakukan dengan metode ELISA (Enzyme Linked Immunosorbent Assay) menggunakan kit ELISA yang hasilnya dalam satuan $\mathrm{ng} / \mathrm{ml}$. Penelitian ini telah memperoleh ethical clearance dari Komisi Etik Penelitian Kesehatan (KEPK) Fakultas Kedokteran Universitas Diponegoro/Rumah Sakit Umum Pusat Dr. Karyadi N0.56/EC/H/FK-RSDK/V/2018. Pengujian hasil kadar hs-CRP dilaksanakan di Laboratorium Pusat Studi Pangan dan Gizi Universitas Gadjah Mada Yogyakarta. Data dianalisis menggunakan paired $t$ test, anova dan post hoc Tukey.

\section{HASIL \\ Karakterisitik Subjek}

Berdasarkan Tabel 1 sebelum dan sesudah pemberian pakan tinggi lemak, kelompok $\mathrm{K}(-), \mathrm{K}$ $(+)$, P1 dan P2 terjadi kenaikan berat badan yang signifikan. Kenaikan berat badan yang paling tinggi terjadi pada kelompok P1 yaitu 69,29\%. Tidak ada perbedaan yang signifikan antar kelompok sebelum dan sesudah pemberian pakan tinggi lemak serta delta perubahan berat badan.

Tabel 1. Karakteristik Berat Badan Sampel Sebelum dan Setelah Pemberian Pakan Tinggi Lemak

\begin{tabular}{|c|c|c|c|c|c|}
\hline \multirow{2}{*}{$\begin{array}{l}\text { Variabel } \\
\text { Berat Badan (g) } \\
\text { Kontrol (-) }\end{array}$} & \multirow{2}{*}{$\begin{array}{l}\begin{array}{l}\text { Sebelum } \\
\text { Rerata } \pm \text { SD }\end{array} \\
138.5 \pm 21.99\end{array}$} & \multirow{2}{*}{$\begin{array}{l}\begin{array}{l}\text { Sesudah } \\
\text { Rerata } \pm \text { SD }\end{array} \\
232.5 \pm 34.39\end{array}$} & \multirow{2}{*}{$\frac{p^{* * *}}{001}$} & \multicolumn{2}{|c|}{$\Delta$ perubahan } \\
\hline & & & & $94.0 \pm 14.7$ & 67.87 \\
\hline Kontrol (+) & $145.7 \pm 20.94$ & $211.9 \pm 29.81$ & 0.006 & $66.25 \pm 35.86$ & 45.47 \\
\hline Perlakuan 1 & $140.7 \pm 27.35$ & $238.2 \pm 22.52$ & $<0.001$ & $97.5 \pm 13.70$ & 69.29 \\
\hline Perlakuan 2 & $140.9 \pm 17.58$ & $224.2 \pm 31.55$ & $<0.001$ & $83.25 \pm 20.1$ & 59.08 \\
\hline$p^{*}$ & 0.956 & 0.472 & & 0.129 & \\
\hline
\end{tabular}

*: uji One WayANOVA; **: uji paired t test

\section{Rerata Berat Badan Tikus}

Berdasarkan tabel 2 sebelum dan setelah pemberian intervensi sari ubi ungu, terjadi peningkatan berat badan yang tidak signifikan pada kelompok K(-) dan $\mathrm{K}(+)$. Pada kelompok P2 terjadi penurunan berat badan yang signifikan dan kelompok
P1 terjadi penurunan berat badan yang tidak signifikan. Terdapat perbedaan BB yang tidak signifikan antar kelompok saat sebelum dan sesudah diberi intervensi sari ubi ungu serta pada delta perubahan berat badan.

Tabel 2. Rerata Perubahan Berat Badan Sebelum dan Sesudah Pemberian Intervensi Sari Ubi Ungu

\begin{tabular}{|c|c|c|c|c|c|}
\hline \multirow{2}{*}{$\begin{array}{l}\text { Variabel } \\
\text { Berat Badan (g) }\end{array}$} & \multirow{2}{*}{$\begin{array}{l}\text { Sebelum } \\
\text { Rerata } \pm \text { SD }\end{array}$} & \multirow{2}{*}{$\begin{array}{l}\text { Sesudah } \\
\text { Rerata } \pm \text { SD }\end{array}$} & \multirow[t]{2}{*}{$p^{* *}$} & \multicolumn{2}{|c|}{$\Delta$ perubahan } \\
\hline & & & & Rerata \pm SD & $\%$ \\
\hline Kontrol (-) & $232.5 \pm 34.39$ & $233.1 \pm 34.62$ & 0.792 & $0.6 \pm 4.74$ & 0.25 \\
\hline Kontrol (+) & $211.9 \pm 29.81$ & $212.4 \pm 24.61$ & 0.902 & $0.5 \pm 9.41$ & 0.23 \\
\hline Perlakuan 1 & $238.2 \pm 22.52$ & $237.9 \pm 20.99$ & 0.908 & $-0.3 \pm 5.05$ & 0.12 \\
\hline Perlakuan 2 & $224.2 \pm 31.55$ & $217.6 \pm 35.38$ & 0.045 & $-6.6 \pm 6.02$ & 2.94 \\
\hline$p^{*}$ & 0.472 & 0.408 & & 0.227 & \\
\hline
\end{tabular}

*: uji One Way ANOVA; **: uji paired t test 


\section{Kadar $h s$-CRP}

Sebelum dilakukan intervensi sari ubi ungu, kadar $h s$-CRP kelompok K (-) berada pada rentang normal sementara pada kelompok $\mathrm{K}(+)$, P1 dan P2 berada diatas batas normal. Setelah intervensi, terjadi penurunan kadar $h s$-CRP yang signifikan pada kelompok $\mathrm{K}(+)$, P1 dan $\mathrm{P} 2$ dan peningkatan tidak signifikan pada kelompok K(-). Perubahan kadar $h s$ CRP terbesar setelah dilakukan intervensi terjadi pada kelompok P2 yaitu terjadi penurunan sebesar $33,33 \%$.
Terdapat perbedaan $h s$-CRP yang signifikan antar kelompok, pada saat sebelum intervensi maupun setelah intervensi. Diketahui bahwa saat sebelum intervensi terdapat perbedaan rerata kadar $h s$-CRP pada kelompok $\mathrm{K}(-)$ dan $\mathrm{K}(+)$, sementara setelah intervensi terdapat perbedaan yang signifikan antar semua kelompok. Perbedaan yang signifikan pada selisih kadar $h s$-CRP sebelum dan sesudah intervensi terjadi antar semua kelompok.

Tabel 3. Rerata Perubahan Kadar hs-CRP Sebelum dan Sesudah Pemberian Intervensi Sari Ubi Ungu

\begin{tabular}{lllcll}
\hline $\begin{array}{l}\text { Variabel } \\
\boldsymbol{h} \boldsymbol{s}-\mathbf{C R P}(\mathbf{n g} / \mathbf{m l})\end{array}$ & $\begin{array}{l}\text { Sebelum } \\
\text { Rerata } \pm \text { SD }\end{array}$ & $\begin{array}{l}\text { Sesudah } \\
\text { Rerata } \pm \text { SD }\end{array}$ & $\boldsymbol{p}^{* *}$ & \multicolumn{2}{c}{$\boldsymbol{\Delta}$ perubahan } \\
\hline Kontrol (-) & $13.8 \pm 13.78^{\mathrm{a}}$ & $14.2 \pm 14.23^{\mathrm{a}}$ & 0.282 & $0.4 \pm 0.20^{\mathrm{a}}$ & 2.89 \\
Kontrol (+) & $23.7 \pm 23.74^{\mathrm{b}}$ & $23.2 \pm 23.24^{\mathrm{b}}$ & 0.047 & $-0.07 \pm 4.70^{\mathrm{b}}$ & 0.29 \\
Perlakuan 1 & $23.9 \pm 24.27^{\mathrm{b}}$ & $19.9 \pm 19.89^{\mathrm{c}}$ & $<0.001$ & $-4.3 \pm 0.79^{\mathrm{c}}$ & 16.73 \\
Perlakuan 2 & $24.3 \pm 23.89^{\mathrm{b}}$ & $16.2 \pm 16.24^{\mathrm{d}}$ & $<0.001$ & $-8.1 \pm 0.45^{\mathrm{d}}$ & 33.33 \\
$p^{*}$ & $<0.001$ & $<0.001$ & & $<0.001$ & \\
\hline
\end{tabular}

*: uji One Way ANOVA **: uji paired t test

${ }_{\mathrm{a}, \mathrm{b}, \mathrm{c}, \mathrm{d})}$ : notasi yang berbeda pada kolom yang sama menunjukkan perbedaan yang bermakna pada uji Tukey

\section{PEMBAHASAN}

Pemberian pakan tinggi lemak mengakibatkan adanya inflamasi pada suatu individu yang ditandai dengan tingginya kadar CRP. ${ }^{22,23}$ Makanan tinggi lemak mengakibatkan hiperplasia dan hipertrofi pada jaringan adiposa serta memicu produksi asam lemak bebas yang tinggi. Produksi asam lemak bebas yang tinggi mengakibatkan adanya aktivasi jalur NF-kB yang mentranskripsi gen cyclooxygenase-2 (COX-2) dan protein inducible nitric oxide (iNOS). Transkripsi COX-2 dan iNOS mengakibatkan munculnya sitokin pro-inflamasi seperti sitokin (TNF- $\alpha$, IL-6 dan IL-1 $\beta$ ) lalu karena sintesis IL-6 yang tinggi akan memproduksi CRP pada hati. Asam lemak bebas yang tinggi juga menyebabkan produksi radikal bebas yang akan menstimulasi mediator inflamasi seperti sitokin TNF$\alpha$, IL-6 dan IL-1 $\beta$ lalu mengakibatkan produksi CRP yang tinggi. . $2,23^{2}$

Penelitian ini menemukan adanya peningkatan berat badan signifikan setelah pemberian pakan tinggi lemak. Tikus pada kelompok K(-) mengalami kenaikan berat badan yang signifikan yang disebabkan karena tikus pada kelompok K(-) selalu menghabiskan pakan standar yang diberikan. Pakan standar yang diberikan memiliki kandungan lemak minimal 3\%, protein 17,5 - 19,5\% dan serat maksimal $8 \%$. Pada kelompok K(+), P1 dan P2 yang disonde pakan tinggi lemak hanya menghabiskan separuh pakan yang diberikan. Kenaikan berat badan yang signifikan pada kelompok $\mathrm{K}(+), \mathrm{P} 1$ dan P2 disebabkan kandungan pakan tinggi lemak yaitu kuning telur bebek yang mengandung $35,80-37,25 \%$ lemak dan minyak babi yang dapat membuat pertambahan berat badan tertinggi yaitu 24,37 gram dalam waktu 4 minggu. ${ }^{24,25}$

Tidak ada perbedaan signifikan pada berat badan tikus antar kelompok setelah pemberian pakan tinggi lemak. Setelah pemberian pakan tinggi lemak berat badan tikus tiap kelompoknya memiliki kenaikan berat badan yang tidak terlampau jauh hal ini disebabkan tikus pada kelompok $\mathrm{K}(-)$ selalu menghabiskan pakan standar yang diberikan sedangkan pada tikus kelompok $\mathrm{K}(+), \mathrm{P} 1$ dan $\mathrm{P} 2$ yang diberikan pakan tinggi lemak tidak menghabiskan pakan standar yang diberikan. Pada penelitian sebelumnya juga didapati hasil tidak adanya perbedaan terlalu jauh data berat badan antar kelompok dengan pemberian pakan tinggi lemak yang sama. ${ }^{26}$ Hal tersebut juga disebabkan pada kelompok $\mathrm{K}(+)$, P1 dan $\mathrm{P} 2$ hanya diberikan pakan tinggi lemak, sedangkan kelebihan berat badan yang terjadi pada obesitas disebabkan karena kelebihan energi. Tingginya kalori atau energi didapatkan dari asupan zat gizi makro berupa karbohidrat, lemak dan protein. ${ }^{27}$ Meskipun tidak memiliki beda berat badan antar kelompok tetapi kadar hs-CRP kelompok yang diberikan pakan tinggi lemak menunjukkan hasil yang lebih tinggi. Pemberian pakan tinggi lemak menyebabkan hiperplasia dan hipertrofi jaringan lemak yang dapat memproduksi asam lemak bebas dan pelepasan adipokin yang akan memproduksi sitokin. Produksi asam lemak bebas tersebut dapat mengaktivasi jalur NF-kB dan memunculkan respon inflamasi yang akan membuat produksi CRP di hati tinggi. 22,23 
Setelah dilakukannya intervensi sari ubi ungu terdapat penurunan berat badan signifikan pada kelompok P2 yaitu 2,94\%. Hal ini terjadi karena ubi ungu dapat menghambat kenaikan berat badan (memiliki efek anti obesitas) pada tikus yang diberikan pakan tinggi lemak. ${ }^{20}$ Antosianin menjadi komponen anti obesitas dengan regulasi jalur Adenosine Monophosphate-Activated Protein Kinase (AMPK) untuk mengurangi ekspresi metabolisme lemak. ${ }^{13}$ AMPK merupakan enzim sebagai bahan bakar yang memonitor perubahan status energi di dalam sel. Saat AMPK teraktivasi, AMPK meghambat jalur anabolisme dan menstimulus katabolisme. ${ }^{28}$ Pada kelompok P1 berbeda hasilnya dengan $\mathrm{P} 2$ yaitu terjadi penurunan berat badan hanya $0,12 \%$ dan bukan penurunan berat badan yang signifikan. Hal ini dimungkinkan karena dosis yang diberikan pada kelompok P1 lebih rendah, seperti pada penelitian sebelumnya yang menunjukkan dengan diberikannya dosis yang lebih rendah memiliki penurunan berat badan yang lebih rendah dan dosis yang lebih tinggi memiliki penurunan berat badan yang lebih tinggi. ${ }^{29}$

Berdasarkan tabel 2 tidak ada perbedaan delta perubahan berat badan antar kelompok setelah pemberian sari ubi ungu. Pada kelompok K(-) dan $\mathrm{K}(+)$ tidak diberikan sari ubi ungu hanya diberikan pakan standar, sehingga tidak ada perubahan berat badan yang berarti. Pada kelompok perlakuan P1 terjadi penurunan berat badan sebesar $0,12 \%$ tetapi tidak signifikan.Pada kelompok perlakuan P1 diberikan dosis 2 gram/200grBB, dosis tersebut lebih sedikit dibandingkan dengan kelompok perlakuan P2 sehingga tidak terjadi penurunan berat badan signifikan. Hal ini membuktikan semakin tinggi dosis pemberian sari ubi ungu akan menurunkan berat badan yang lebih tinggi.

Sebelum dilakukannya intervensi sari ubi ungu, kadar hs-CRP kelompok K(-) dalam rentang normal sedangkan pada kelompok $\mathrm{K}(+), \mathrm{P} 1$ dan P2 diatas batas normal karena pada tiga kelompok tersebut diberikan pakan tinggi lemak sehingga terjadi inflamasi yang menyebabkan kadar hs-CRP tinggi. Hasil dari proses tersebut adalah hipertrofi adiposit dengan simpanan trigliserida yang besar dan akan menghasilkan laju lipolitik yang tinggi, akan memproduksi leptin lebih lagi dan kurang adiponektin. Efek akibat hipertrofi sel lemak adalah adanya infiltrasi jaringan lemak dengan makrofag. Hipertrofi yang terjadi adalah hipertrofi pada jaringan adiposa putih yang paling banyak meningkat pada orang yang terkena obesitas. Meningkatnya jaringan adiposa putih berkaitan dengan inflamasi karena terdapat makrofag di dalamnya. ${ }^{23}$ Adanya interaksi adiposit dan makrofag berkontribusi dalam produksi sitokin. Proses ini juga berkontribusi dengan adanya inflamasi dan resistensi insulin. ${ }^{30}$

Setelah dilakukan pemberian intervensi sari ubi ungu terdapat penurunan signifikan kadar hs-CRP pada kelompok $\mathrm{K}(+)$, P1 dan P2 namun belum mencapai kadar normal. Kadar normal hs-CRP tinggi atau dikatakan telah terjadi inflamasi jika lebih dari $15,5 \mathrm{ng} / \mathrm{ml} .^{31}$ Antosianin yang terkandung pada ubi ungu menunjukkan perlawanan yang kuat akan adanya radikal bebas, signifikan dalam mengurangi tekanan darah dan memiliki anti-inflamasi, antimikroba dan efek proteksi terhadap ultraviolet. ${ }^{32}$ Selain mengandung antosianin, ubi ungu juga mengandung senyawa fenolik lainnya dengan antioksidan dan aktivitas anti-inflamasi. ${ }^{13}$ Mekanisme umum antioksidan dalam menghilangkan stres oksidatif adalah dengan menghambat, mencegah dan menunda terjadinya oksidasi dengan menghilangkan sumber radikal bebas dan mengurangi stres oksidatif. ${ }^{17}$ Setelah intervensi juga ditemukan beda antar kelompok dan perbedaan delta perubahan kadar hs-CRP yang signifikan. Terjadi penurunan kadar hs-CRP signifikan pada kelompok $\mathrm{K}(+)$ yang tidak diberikan intervensi sari ubi ungu dapat disebabkan karena mekanisme penurunan respon inflamasi. Pada 24-48 jam setelah inflamasi terjadi kenaikan kadar CRP yang kemudian kadarnya akan menurun pada hari selanjutnya. ${ }^{33}$ Intervensi diberikan selama 6 hari dan pada rentang waktu tersebut kadar hs-CRP kelompok $\mathrm{K}(+)$ dapat mengalami penurunan dengan sendirinya tanpa diberikannya intervensi sari ubi ungu.

Penurunan kadar hs-CRP pada kelompok P2 jauh lebih besar dibandingkan pada kelompok P1. $\mathrm{Hal}$ ini disebabkan karena pemberian intervensi yang berbeda. Kelompok P2 yang diberikan dosis ubi ungu 3 gram/200grBB mengalami penurunan sebesar $33,33 \%$, penurunan tersebut terjadi hampir $2 x$ lipat dibandingkan dengan kelompok P1 yang diberikan dosis 2 gram/200grBB yang hanya mengalami penurunan sebesar $16,73 \%$. Dosis yang diberikan pada P1 memiliki kandungan antosianin 2,21 mg/200grBB sedangkan pada kelompok P2 memiliki kandungan antosianin $3,31 \mathrm{mg} / 200 \mathrm{grBB} .{ }^{34,35}$ Pada sari ubi ungu mengandung antosianin yang tinggi. ${ }^{14,16}$ Antosianin menghambat ekspresi cyclooxygenase-2 (COX-2) atau menghambat protein inducible nitric oxide (iNOS) suatu gen yang terlibat dalam banyak proses inflamasi. Gen-gen tersebut ditranskripsi oleh nuclear factor-kB (NF-kB). NF-kB juga berperan dalam mentranskripsi beberapa sitokin pro-inflamasi seperti TNF- $\alpha$, IL-1 $\beta$, Il-6. ${ }^{17}$ Pada ubi ungu tidak hanya antosianin saja yang sebagai antioksidan, tetapi ada beberapa antioksidan lain seperti vitamin $\mathrm{C}$, vitamin $\mathrm{E}, \beta$-karoten dan protein. Vitamin $\mathrm{C}$ mengurangi kadar CRP dengan menghambat 
lipopolisakarida yang menstimulasi produksi IL-6, TNF- $\alpha$ serta IL-2, selain itu vitamin $C$ juga menghambat aktivasi NF-kB. ${ }^{36}$

Pengonsumsian ubi ungu dapat dijadikan cemilan dan minuman sari ubi ungu untuk mengoptimalkan kandungan antosianin pada ubi ungu. Tidak perlu adanya pengurangan konsumsi karbohidrat dalam bentuk nasi untuk menjadikan ubi ungu sebagai cemilan karena hanya dikonsumsi dalam porsi kecil. Minuman sari ubi ungu dapat dibuat dengan menggunakan juicer atau dengan menggunakan blender, untuk mendapatkan sari ubi ungu dengan cara manual yaitu disaring. Berdasarkan informasi nilai gizi minuman sari ubi ungu didapatkan keterangan yaitu kandungan karbohidrat $53,23 \% / 100$ gram, protein 2,27\%/100 gram dan antosianin $0.153 \% .{ }^{37}$ Pada penelitian sebelumnya didapatkan hasil sari ubi ungu dengan proses pemanasan $70^{\circ} \mathrm{C}$ dalam 5 menit adalah $90,63 \mathrm{mg} / \mathrm{l}^{38}$

\section{SIMPULAN}

Sari ubi ungu dapat menurunkan kadar hsCRP secara signifikan. Penurunan kadar hs-CRP yang lebih tinggi terjadi pada kelompok perlakuan 2 dengan dosis $3 \mathrm{gr} / 200 \mathrm{grBB}$.

\section{SARAN}

Intervensi perlu dilakukan dalam waktu tidak lebih dari 14 hari untuk mencapai kadar hs-CRP yang normal yaitu kurang dari 15,5 ng/ml.

\section{DAFTAR PUSTAKA}

1. IDAI. Diagnosis, Tata Laksana dan Pencegahan Obesitas pada Anak dan Remaja. 1st ed. Ikatan Dokter Anak Indonesia. Jakarta: Ikatan Dokter Anak Indonesia; 2014. 1 p.

2. Rachmi CN, Li M, Baur LA. Overweight and Obesity in Indonesia: Prevalence and Risk Factors-a literature review. Elsevier. 2017;7:21.

3. Badan Penelitian dan Pengembangan Kesehatan Kementerian Kesehatan RI. Riset Kesehatan Dasar. 2013;

4. Kementrian Kesehatan Republik Indonesia. Situasi Gizi. Jakarta; 2016.

5. Kuozmarski RJ. What is Obesity? Definitions Matter. In: Kumanyika S, Brownson RC, editors. Handbook of Obesity Prevention: A Resource for Health Professionals. New York: Springer Science; 2007. p. 25.

6. Coelho DF, Chaves DS, Diwan D, Ferraz R, Poortmans JR, Junior AHL. Effect of High-Fat Diets on Body Composition , Lipid Metabolism and Insulin Sensitivity, and The Role of Exercise on These Parameters. Brazilian J. 2011;44(October):967.

7. Navarro P, de Dios O, Jois A. Vegetable and
Fruit Intakes Are Associated with hs-CRP Levels in Pre-Pubertal Girls Pilar. Nutrients. 2017;9:1-10.

8. Nappo A, Iacoviello L, Fraterman A, Gonzalezgil EM, Hadjigeorgiou C, Marild S, et al. Highsensitivity C-reactive Protein is a Predictive Factor of Adiposity in Children: Results of the Identification and prevention of Dietary- and lifestyle-induced health Effects in Children and Infants (IDEFICS) Study. Am Hear. 2013;1-9.

9. Wilson PWF. Obesity and Heart Disease. In: Handbook of Obesity Epidemiology, Etiology, and Physiopathology. Third Edit. New York: CRC Press; 2014. p. 515.

10. Lysen LK, Israel DA. Nutrition in Weight Management. In: Kathleen ML, Raymond, L J, editors. Krause's food \& the nutrition care process. Fourteenth. Canada: Elsevier Inc.; 2017. p. 387.

11. C. Akoh C. Dietary Fatty Acids, Lipid Mediators, Immunity and Inflammation. In: Food Lipids Chemistry, Nutrition and Biotechnology. Fourth. CRC Press; 2017. p. 627.

12. Wu Q, Qu H, Jia J, Kuang C, Wen Y, Yan H, et al. Characterization, Antioxidant and AntitumorAactivities of Polysaccharides from Purple Sweet Potato. Carbohydr Polym. 2015;132:31-40.

13. Wang S, Nie S, Zhu F. Chemical Constituents and Health Effects of Sweet Potato. Food Res Int. 2016;89:90-116.

14. Shinha J et al. Effect Of Cooking Methods On $\beta$ Carotene, Anthocyanin, Vitamin $\mathrm{C}$ And Antioxidant Content Of Sweet Potato. Int J Food Nutr Sci. 2015;4(3):1-4.

15. Wang L, Zhao Y, Zhou Q, Luo C-L, Deng A-P, Zhang Z-C, et al. Characterization and Hepatoprotective Activity of Anthocyanins from Purple Sweet Potato (Ipomoea batatas L.). J Food Drug Anal. 2016;(8).

16. Daniela Ticoalu G, Mahar Maligan J. Pemanfaatan Ubi Ungu (Ipomoea batatas) Sebagai Minuman Berantosianin dengan Proses Hidrolisis Enzimatis. J Pangan dan Agroindustri. 2016;4(1):46-55.

17. Miguel MG. Anthocyanins: Antioxidant and Anti-Inflammatory Activities. J Appl Pharm Sci. 2011;1(6):7-15.

18. Pil Y, Ho J, Hee E, Gyun H, Wee J. Purple Sweet Potato Anthocyanins Attenuate Hepatic Lipid Accumulation through Activating Adenosine Monophosphate - Activated Protein Kinase in Human HepG2 Cells and Obese Mice. Nutr Res [Internet]. 2011;31(12):896-906. Available from: http://dx.doi.org/10.1016/j.nutres.2011.09.026 
19. Pil Y, Ho J, Min J, Chul Y, Gwang H. Protective Mechanisms of Anthocyanins From Purple Sweet Potato Against Tert -butyl Hydroperoxide-Induced Hepatotoxicity. Food Chem Toxicol. 2011;49(9):2081-9.

20. Shan Q, Zheng Y, Lu J, Zhang Z, Wu D, Fan S, et al. Purple Sweet Potato Color Ameliorates Kidney Damage Via Inhibiting Oxidative Stress Mediated NLRP3 Inflammasome Activation in High Fat Diet Mice. Food Chem Toxicol. 2014;69:339-46.

21. Patel V, Patel R. The Active Constituents of Herbs and Their Plant Chemistry, Extraction and Identification Methods. J Chem Pharm Res. 2016;8(4):1423-43.

22. Kaur J. A Comprehensive Review on Metabolic Syndrome. Cardiol Res Pract. 2014;2014.

23. Fernández-Sánchez A, Madrigal-Santillán E, Bautista M, Esquivel-Soto J, Morales-González Á, Esquivel-Chirino $\mathrm{C}$, et al. Inflammation, Oxidative Stress, and Obesity. Int J Mol Sci. 2011;12(5):3117-32.

24. Ganesan $P$, Korea $S$, Kaewmanee $T$. Comparative Study on the Nutritional Value of Pidan and Salted Duck Egg. Korean J Food Sci. 2014;34(February).

25. Kusumastuty I, Andarini S, Anom Aswin AAG. Perbedaan Pengaruh Pemberian Minyak Kelapa Sawit (Palm Oil) Dan Minyak Kelapa Murni (Virgin Coconut Oil) Terhadap Perbaikan Profil Lemak (Kolesterol) Pada Tikus Dengan Diet Aterogenik. J Kedokt Brawijaya. 2006;

26. Setyono J, Nugroho DA, Mustofa, Saryono. Efek Orlistat, Ekstrak Biji Kopi Hijau, dan Kombinasinya terhadap Kadar Adiponektin dan Profil Lipid. Ners. 2014;9:27.

27. Hill JO, Wyatt HR, Peters JC. Energy Balance and Obesity. Natl Inst Heal. 2013;126(1):12632.

28. Gaidhu MP, Ceddia RB, Bacis R. Remodeling Glucose and Lipid Metabolism Through AMPK Activation: Relevance forTreating Obesity and Type 2 Diabetes Remodeling Glucose and Lipid
Metabolism Through AMPK Activation: Relevance for Treating Obesity and Type 2 Diabetes. Clin Lipidol. 2017;4299:465.

29. Shin SJ, Bae UJ, Ahn M. Aqueous Extracts of Purple Sweet potato Attenuate Weight Gain in High Fat-fed Mice. Int J Pharmacol. 2013;9:42.

30. Mathieu P, Lemieux I, Després J-P. Obesity, Inflammation, and Cardiovascular Risk. Clin Pharmacol Ther. 2010;87(4):407-8.

31. Sarmen S, Bachtiar H. High Sensitivity CReactive Protein sebagai Parameter Diagnostik dan Prediktor Luaran Sepsis pada Anak yang Menderita Systemic Inflammatory Systemic Syndrome. Vol. 16, Sari Pediatri. 2014.

32. Rodrigues N da R, Barbosa JL, Barbosa MIMJ. Determination of Physico-chemical Composition, Nutritional Facts and Technological Quality of Organic Orange and Purple-fleshed Sweet Potatoes and Its Flours. Int Food Res J. 2016;23(5):2071-8.

33. Thurnham DI, Mccabe GP. Influence of Infection and Inflammation on Biomarkers of Nutritional Status with an Emphasis on Vitamin A and Iron. Panama; 2012.

34. Ginting E, Utomo JS, Yulifianti R. Potensi Ubijalar Ungu sebagai Pangan Fungsional. Iptek Tanam Pangan. 2011;6(1):116-38.

35. Organization IL. Kajian Ubi Jalar dengan Penedekatan Rantai Nilai dan Iklim Usaha di Kabupaten Jayawijaya. 2015.

36. Block G, Jensen CD, Dalvi TB, Norkus EP, Crawford PB, Holland N, et al. Vitamin C Treatment Reduces Elevated C-Reactive Protein. Natl Inst Heal. 2010;46(1):70-7.

37. Lodge H, Brook O. Purple Sweet Potato Juice Concentrate. 2013.

38. Dwiyanti G, Siswaningsih W, Febrianti A. Production of Purple Sweet Potato ( Ipomoea batatas L .) Juice having High Anthocyanin Content and Antioxidant Activity Production of Purple Sweet Potato ( Ipomoea batatas L .) Juice having High Anthocyanin Content and Antioxidant Activity. J Physic. 2018;1013:1-2. 